\title{
Vapaan sivistystyön moniottelua
}

Sari Virtanen \& Ville Marjomäki (toim.). Kansanopistokirja. Kansanvalistusseura 2005 \& Mauri Nest (2005). Kansan, sivistyksen tähden. Severi Nuormaan vaiheita kansallisen murroksen vuosina. Pilot-kustannus Oy.

$\mathrm{K}$ ansanopistoyhdistyksen juhlakirja ja varhaisen kansansivistyksen moniottelijan Severi Nuormaan elämänvaiheiden kautta vapaata sivistystyötä peilaava teos tarjoaa kaksi toisiaan täydentävää näkökulmaa siihen, mitä vapaa sivistystyö on ollut ja on. Teokset ovat myös kovasti ajankohtaisia, eikä vähiten siksi, että niissä päädytään pohtimaan tämän ja huomisen päivän haasteita.

Kansanopistokirjaan on koottu viidentoista, pääasiassa kansanopistokentän edustajan esityksiä ja pohdintoja kansanopistosta aikakausiensa kuvastimena ja vaihtoehtojen tarjoajana. Kolmannen näkökulman muodostaa kansanopistojen edunvalvonta.

Kirjoittajien joukossa ovat muun muassa kansanopistoista hiljattain väitelleet Helena Koskinen sekä Päivi TuomolaKarp. Linköpingin yliopiston lehtori Lisbeth Eriksson tuo teokseen perinteisen pohjoismaisen näkökulman. Hän pohtii etnisen monimuotoisuuden ja monikulttuurisuuden haasteita ruotsalaisen kansanopistokentän kokemuksiin perustuen. Jokaisen kirjan kolmesta kappaleesta päättää lyhyt kansanopisto-opiskelijan kuvaus omista kansanopistokokemuksistaan.

Kirjan artikkelit läpi luettuani mieleeni on painunut erityisesti suomenruotsalaisen kansanopisto-opettajan Matts Granön artikkelin otsikko "Vai- keasti tavoitettava identiteetti". Toimintavolyymiltaan pieni vapaan sivistystyön organisaatiomuoto tarjoaa lähes kaikkea perusopetuksesta yliopistolliseen arvosanaopetukseen. Se hyödyntää aktiivisesti ulkoisen säätelyn vähäisyyteen perustuvaa vapauttaan. Kansanopisto on (aikuis)koulutuksen todellinen moniottelija, alati väriään vaihtava kameleontti. Se on kuin mp3-soitin; pieni, ketterä ja tehokas. Kansanopisto ei ole joko-tai - se on sekä-että. Mutta-moni kirjoittajista peräänkuuluttaa myös näyttöä sivistyksestä, keskittymistä vapaaseen sivistystyöhön, itsenäistä kantaa yhteiskunnan muutokseen sekä ihmisen paikkaan ja tehtävään muutoksen pyörteissä. Vieläkin pidemmälle voi toki mennä. Kansanopisto voi(si) uida vastavirtaan, tarjota todellisia vaihtoehtoja ja vastustaa eliittikulttuuria. IIman näitä identiteetti saattaa käydä yhä haaleammaksi. Näin toteaa Työväen Sivistysliiton pääsihteeri Jorma Turunen.

\section{Neljä diskurssia, neljä tapaa hahmottaa}

Tunnistan Kansanopistokirjan artikkeleissa neljä toisiaan täydentävää ja haastavaa diskurssia; kirjoitustyyliä, tapaa tarkastella ja hahmottaa vapaata sivistystyötä kansanopistoissa.

Historiallisessa tarkastelutavassa kansanopiston juuret ovat vahvasti Grundtvigin elävään sanaan ja vuorovaikutukseen perustuvassa sivistyskäsityksessä. Kansanopisto oli suomalaiselle talonpoikaisnuorisolle kansallisuusaatteen kultaaikana perustettu tiedollisen, käytännöllisen ja kansalaiskasvatuksen yhdistämään kyennyt sisäoppilaitos. Tähän samaan perinteeseen liittyvät myös aatteellisen moniarvoistumisen myötä perustetut kristilliset sekä poliittisiin edunvalvontajärjestöihin aikoinaan kytkeytyneet opistot.

Historiallisen tarkastelutavan vastakohdaksi asettuu tarkastelutapa, jossa kansanopisto esitetään suorituskykyisenä koulutusmarkkinaorganisaationa. Tämä, osittain retorinen tarkastelutapa muodostuu sekä elinikäisen oppimisen politiikan että markkinamenestykseen sitoutuneesta organisaatioteoreettisesta sanastosta. Sosiaalisen pääoman kasvuun ja tunneälyn vahvistamiseen pyritään asiakaskeskeisyydellä, tuoteprofiloinnilla sekä strategiajohtamisella.

Taloudellishallinnollinen tarkastelutapa muodostaa tavallaan jatkumon kahden edellä mainitun välille. Siinä missä muinoin valtionapua sai eritoten käytännönläheisten talonpoikaistalouden tarpeita palvelevien kurssien järjestämiseen, panostetaan osassa kansanopistoista tänään tutkintotavoitteiseen ammatilliseen koulutukseen. Kansanopistoissa tehtyjä periaatteellisia ratkaisuja on osittain aina määrittänyt, Heikki Sederlöfin sanoin, "tuottoisimman koulutuksen realiteet- 
ti: sitä tehdään millä tienaa".

Siellä täällä Kansanopistokirjan sivuilla välähtää myös vaihtoehtoinen tarkastelutapa, vastadiskurssi. Se kiinnittyy sivistyksen ajatukseen ja käsitteeseen. Muutamassa tekstissä kirjoitetaan sivistystehtävästä ja sivistysrealismista-hahmotellaan sivistyksen paluuta. Luettuani Kansanopistokirjan päädyn toteamaan, ettei Suomessa ole vain yhtä kansanopistoa. Niitä on 91. Ne kuuluvat kaikki, kuten Ville Marjomäki kirjan alussa toteaa, Suomen kansanopistoyhdistykseen.

\section{Sivistyshistoriaa Severi Nuormaan elämän kautta}

Pälkäneen seudun kansalaisopiston rehtori Mauri Nest toteaa Severi Nuormaa -kirjansa alussa halunneensa tarttua mahdollisimman epämuodikkaaseen aiheeseen. Tulkitsen hänen asemoivan itsensä edellä mainittuun vastadiskurssiin. Mutta onnistuuko hän olemaan epämuodikas? Kyllä ja ei. Mauri Nest korostaa sitä, ettei hän ole kirjoittanut Severi Nuormaan elämäkertaa. Hän pyrkii kuvaamaan yksittäisen henkilön elämän eri vaiheiden kytkeytymistä siihen kansalliseen ja yhteiskunnalliseen muutokseen, jossa vapaa sivistystyö syntyy.

Severi Nuormaa on otollinen kohde, hieman levoton kulttuuri- ja sivistystyön moniottelija. Hän on, kuten moni muukin muistetuista aikalaisistaan, hieman kaikkea: tutkija, lehtimies, poliitikko, runoilija, kääntäjä sekäkansansivistäjä.

Severi Nuormaa toimi Hämeen kansanopiston ja Tampereen työväenopiston ensimmäisenä johtajana. Hän kirjoitti jälkimmäisenä mainitun opiston perustamisvuonna 1899 tiettävästi maamme ensimmäisen aikuisdidaktiikan opetusoppaista, otsikolla "Kansanomaisesta opetustavasta."Tässäkirjasessa Nuormaa tuntuu Nestin tulkinnan (s. 75) mukaan "... ajavan takaa kokonaisvaltaista, aikuisen oppijan elämäntilanteen hahmottamista - ja hänen katsantokannallaan on vahvasti eettinen, opiskelijaa ja kanssainmistä kunnioittava lähestymistapa". Sekä muodikasta että vähemmän muodikasta.

Severi Nuormaan sortokauden aikaiset julkiset esiintymiset omassa opistossaan sekähänen lehtikirjoittelunsa johtivat siihen, että hän joutui pakenemaan maastakarkoituksen uhkaa Yhdysvaltoihin. Muutaman vuoden jälkeen hän palasi takaisin kotimaahansa toimien vuosien varrella useiden lehtien toimituksissa, erilaisissa luottamustehtävissä sekä lähes vuosikymmenen Turun työväenopiston "jatkuvan tarkkailun alaisena" johtajana. Kaiken muun ohella hän julkaisi säännöllisesti runokokoelmia. Mauri Nest limittää Nuormaan runoja elämän vaiheiden kuvaukseen.

\section{Kansan, sivistyksen tähden}

Lukemani kirjan otsikko ei ole "Kansansivistyksen tähden" vaan "Kansan, sivistyksen tähden”. Tällä Mauri Nest viittaa siihen jännitteiseen tilanteeseen, johon ihminen, tässä tapauksessa kansansivistää itsensä yhteiskunnallisessa murrostilanteessa asettaa. Jännitettä ja ristiriitaa syntyy sekä tavoitteiden ja mahdollisuuksien että ihanteiden ja todellisuuden välille. Nest toteaa (s. 167), että kansansivistäjän kannalta di- lemma aiheutuu hänen suhteestaan kansaan ja sivistykseen. "Kansansivistäjän työn lähtökohdat olivat yleensä jonkin yhteiskunnallisesti hegemonisen tahon yhteisessä aatteellisessa formuloinnissa. Näistä lähtökohdista haluttiin edistää yhteiskunnallista kehitystä, koheesiota ja väestön sosialisaatiota". Ei kovinkaan epämuodikasta!

Kirjan Iopussa Mauri Nest päätyy, Severi Nuormaan elämänvaiheiden taustoittamana, pohtimaan ja haastamaan vapaan sivistystyön itseymmärrystä omassa ajassamme. Instituutioiden realiteetit, joihin Kansanopistokirjassa tämän tästä viitataan, sanelevat hänen mukaansa (s. 181) "..liian usein vapaan sivistystyön itseymmärryksen mahdollisuuden".

Nest peräänkuuluttaa uusia tulkintoja sekä itsestäänselvyyksien problematisointia. Hän katsoo vapaan sivistystyön muuttuneen sopeutuvaksi ja sopeuttavaksi sosiaali-ja innovaatiotoiminnan välineeksi. Tämän seurauksena se on ajautunut shokinomaiseen itsesäätelyn tilaan. Tässä tilassa sen organisaatioista on tullut luovia, koulutustehtävistä ja asiakkaista kilpailevia, vahvempien kanssa verkostoituneita mielikuvakoulutuksen tarjoajia.

Mitä tehdä? Sekä Mauri Nest että Seppo Niemelä, Kansanopistokirjan viimeisessä artikkelissa, esittävät omat vaihtoehtonsa. Ne ovat lukemisenarvoiset.

PETRISALO 